\title{
Queer Male (Post)Soviet Narratives in Interviews by Rita Ruduša and Fiktion by Klāvs Smilgzieds ${ }^{1}$
}

\author{
KĀRLIS VĒRDIN̦Š
}

\begin{abstract}
One culture within a culture is the culture of LGBT people in Latvia or, to use a contemporary designation, queer culture. In Latvia, queer culture is still practically invisible. In this paper I will analyse two types of queer narratives: documentary life stories collected by Rita Ruduša in her book Forced Underground (2012) and the manuscript of a collection of 12 short stories by Klāvs Smilgzieds (2014), originally published serially during the 1990s in an underground Latvian gay magazine. Both types of texts employ different emphasis talking about queers in Soviet and post-Soviet life. Ruduša's interviews reflect on the situation of being in the closet and on fear and loneliness, while Smilgzieds' stories celebrate the male body, casual sex, and unfulfilled loves. While Ruduša's interlocutors (mostly gay men, more or less closeted) construct their narratives to seem acceptable to straight women, Smilgzieds, a closeted bisexual himself (or, as he calls himself in Latvian, divdabis), uses various modes of narrative (parable, miniature, pornographic prose) to express both his experience and imagination. Both Ruduša and Smilgzieds reveal the slow changes in consciousness taking place in Latvia in its transition from a Soviet to a postSoviet society that result in actions such as the decriminalization of male homosexuality, the existence of LGBT organizations and clubs, the use of queer issues as topics for tabloids and TV shows etc. The habitus of gay people is changing very slowly as a consequence. In this paper the construction of queer Latvian narratives is analysed in comparison to other queer narratives.
\end{abstract}

Keywords: life stories, oral history, fiction, homosexuality, LGBT studies

\section{Collecting the life stories of post-soviet Latvians}

After the regaining of independence in Latvia, a lot of research has been carried out in order to collect the life stories of people that lived through the period of Soviet occupation and to analyse their experiences. The Oral History Archive was

1 This work has been supported by the European Social Fund within the project "Cultures within a Culture: Politics and Poetics of Border Narratives" (Nr.1DP/ 1.1.1.2.0/13/APIA/VIAA/042) 
founded in 1992 and later it became a part of the Institute of Philosophy and Sociology. The personal experiences of people are at the centre of this research process.

As Ieva Garda-Rozenberga has stated, "The life story interviews obtained by the researchers are regarded as socially constructed texts, as dialogues between the researcher and his or her respondents that exist in a particular social and cultural context. [...] Generally, life stories have been regarded as narrative constructions where the relationship between life and its rendition is intermediated by memory, consciousness, language, situation of interaction, rules of communication, experience of other stories as well as knowledge of the public social processes." (Garda-Rozenberga 2012: 9-10)

Life stories can be described as situative, spontaneous, and uncensored because there is no time for careful and long-lasting self-censorship during the interview. The life story of the interviewee is born during the interaction with the interviewer who can be defined as a co-author of the source, partially contributing to its content - the attitude of the interviewer during the interview, as well as questions asked and the in interviewer's reaction to the story are important factors contributing to the final result.

It is characteristic of both the narratives collected and the published stories that they often fall into nationalistic discourse, accenting the importance of ethnic origin, identifying himself or herself as a representative of a certain nation responsible for the reputation of that group and the maintenance of all the associated good qualities of that group. Ieva Garda-Rozenberga defines the mode of these interviews in her project Dzivvesstāsts un pašapzina: mutvärdu vēsture Latvijā (Life-Story and Self-Awareness: Oral History in Latvia): "Both narrator and interviewer are involved in the meaningful event of narration when the narrator's life is transformed into a story and the cup of national self-awareness can be filled." (Garda-Rozenberga 2012: 11)

Such a description can be understood as the glorification of "national selfawareness" or a process during which a "right" story is born through collaborative effort, which is meant to replace all "wrong" stories that probably could be told by other people with less "national self-awareness". However, the scope of Latvian oral history researchers has grown wider and strives to include a reflection of the stories of other social groups within Latvia, for example, interviews with representatives of the Latvian gypsy community.

As English oral historian Paul Thompson has noted, the purpose of the oral history, apart from historical study, is to give voice to marginalised and forgotten groups and individuals - to listen to their stories and to offer them the chance to express their own perspectives in order to broaden our perception of history. His viewpoint is a socialist one and he speaks of the importance of uniting the stories of various social groups in a national oral history. (See Thompson 2000) 
VĒRDIN̦Š

New mechanisms have been created in Latvia to maintain a common historical perspective that regulate the nation's memory of itself and its representations. The accentuation of trauma also plays a significant role in the creation of a common historical perspective when certain groups are marked as victims or aggressors and the distinction between "us" and "them" is intensified. To be able to perceive the variety of experience of the Soviet period and to understand the collective memory as uneducable to some particular dominant historical narrative, we must also listen to memories that, at first glance, don't fit into the politically constructed view. (Garda-Rozenberga 2012: 53-56)

Deniss Hanovs has written about the problem of the "wrong" view of history that is held by a portion of the Latvian population; attitudes to the Soviet period and memories of the Second World War can differ significantly among the various ethnic groups in Latvian society. (Hanovs 2012)

Apart from the ethnic and social minorities, another group of people, which, until recently, hasn't been given a voice, is the queer or LGBT community in Latvia. Their memories still seem to be "wrong", and, as far as I know, their experiences are not usually included in the oral history archives. This is a group that could be easily victimized-during the Soviet period; they were bound by both the law and by social attitudes. Even during the past twenty-two years, after the decriminalisation of male homosexual relations, the status of queers has remained low in the public eye because of the lasting imprint of homophobic thinking. As Pēteris Timofejevs-Henriksson notes in his article on the present situation of Latvian LGBT people, "In the modern Latvia, nationalist and populist politicians take political advantage of these deep 'imprints' by framing the LGBT community in terms of the dangerous Other that is constructed as a political threat to the purity of Latvianness." (Timofejevs-Henriksson 2013:112; see also Waitt 2005 and Mole 2011.)

If the LGBT community can be taken as a homogeneous group of people with its own traditions and even folklore, as in the Encyclopedia of Homosexuality, which contains articles on gay and lesbian folklore, it is possible to speak of particular stories that are characteristically shared among gay people, for example, the personal experience narrative:

Stories of this sort are not traditional in themselves, but the narrators have told them so often that they have taken on a traditional structure. The most familiar type of personal experience narrative among homosexual men is the coming-out story, in which a man describes revealing his homosexuality to someone (usually friends or family). Most gay men have more than one coming-out story, since one comes out to different people at different times. (Goodwin 1990: 413) 
In this paper two ways of telling personal experience stories will be analysed: interviews of representatives of the Latvian LGBT community made by Rita Ruduša will be compared to gay-themed short stories written by Klāvs Smilgzieds. Both the fictional and the true stories can be analysed in terms of how open the author can be about his (her) emotional and sexual experience, what features they take as characteristic of their identity, and in what ways having no voice and being "in the closet" can be overcome.

\section{The inverted fig leaf: life stories in interviews by Rita Ruduša}

From 1987 until 1992, when homosexuality entered the public discourse in Latvia, periodicals mostly published interviews with "experts" - Soviet sexologists or representatives of the justice system who expressed their confusion and awkwardness when being questioned on such topics (see Vērdiňš \& Ozoliņš 2013). At the beginning of 90 s, homosexuals were given their own voice, however, these voices were mostly anonymous. Four interviews with gay men by Ieva Lešinska were published in Rigas Laiks in 1994. In 1995, a Latvian translation of a book of interviews by East German journalist Jürgen Lemke, Ganz normal anders, was published by a marginal publishing house, Kukors, in Daugavpils.

From 2010 to 2012, journalist Rita Ruduša carried out her project, interviewing homosexuals in Latvia (including three people that had emigrated to the United Kingdom), that had experienced both Soviet and post-Soviet life. The Latvian edition was published in 2012, an English edition followed two years later. The book contains 12 chapters that include various queer narratives: the authors' childhood memories of a homosexual man living next door; a one page story explaining how its lesbian protagonist shared her experience and was later banned from publishing it; stories from lesbian Signe and transsexual Olga, as well as stories told by public Latvian gay figures Māris Sants and Kārlis Streips. The rest of the interviews tell the stories of six anonymous gay or bisexual men of various ages - from Māris the pensioner to Dainis the gypsy, whose sex life started in the 1990s.

As Ruduša acknowledges, the names and locations in these stories have been changed to protect the identities of her anonymous informants. Since their life stories do not go into detail, we know almost nothing of their tastes, hobbies, or other important life experiences beyond their sexuality, their reflections on existential problems, and, in some cases, their contributions to gay activism in post-soviet Latvia. Their identities are portrayed as an inverted fig leaf - in order to expose their sexual identities, they have to hide other aspects of their lives to remain anonymous, because many of them have still not come out to their 
VĒRDIN̦Š

parents and other relatives. Some of them still dream of experiencing a "normal" life - having a partner of the opposite sex, having children, and following "traditional" values, despite their sexual drives. Their dreams are based on the assumption that gay life is meant only for young people who are desirable and can easily find sex partners, but old age can bring only loneliness and despair.

Ruduša's interviews draw a map of Latvian gay geography that includes cruising places, bars, and beaches. During the Soviet era, this map consisted of the "long circle" and the "short circle" in the centre of Riga, which included some of the most crowded streets and parks next to the University of Latvia and the National Opera, public toilets in the Riga city centre, unofficial gay beaches in Lielupe and Kalngale, the bar Skapis (an ironic choice of name since the English translation means 'closet') and some other "gay-friendly" cafés. Of course, not everybody enjoyed the opportunity for public encounters. Aivars, one of Ruduša's protagonists recalls, "when I found out that gays have sex in toilets, I felt nauseous" (Ruduša 2014: 43).

Various clubs have been added to the map during the Post-soviet period, mostly in spaces that were adapted to serve the need for gay disco venues during weekends such as Straume and Aptiecina. Gradually they were replaced by more stable and public gay clubs such as Purvs, 808, XXL and others, where Ruduša's protagonists have spent significant amounts of time since the 1990s.

Ruduša presents her stories in a way that is intended for wide audience. For example, two of the aforementioned respondents, Māris and Dainis, are reported to have told a lot about their sexual experience with different partners, however, Ruduša cuts their explicit narratives short and leaves only details that would not seem pornographic for her mainstream audience, concentrating on their emotional experiences and their opinions on life as closeted homosexuals:

Māris had to learn to manoeuvre, act and pretend constantly, in both his lives. He has had hundreds of homosexual partners, but only three know his real name, he has never given anyone his phone number, and only a few have seen his territory (the summer cabin). He believes the heterosexual façade has been convincing and no one in his family suspects he has this "hobby" (well, maybe one of his sons does, but Māris has no intention of confirming his suspicion. (Ruduša 2014: 32)

A different version of Māris' life story can be found in his memoirs, published in the underground gay magazine Elwis already in 2002 under the same author's name. Many details overlap, and gay reader can also enjoy the explicit sexual content that has been cut from the mainstream version of the interview. In these passages, Māris carefully recounts his sexual partners, evaluates the pleasure 
he received from them, their technique, and the expectations that either made them suitable for regular secret dates or gradually estranged him from them (Māris, 2002).

All this information might seem pointless or even disgusting for mainstream audience, still for gay readers it can be valuable as stories of personal experience, as potential guide in queer ethics or just as collection of sex advices. In the Elwis version, Māris does not pay much attention to the fact of his double life - his sexual encounters are perceived as much more important than the everyday routine he has with his family. Ruduša also asks questions about the liminal situations in such a life - the moments when he "switches" to his heterosexual identity after a date with another man:

I ask - how was it possible to switch from homosexuality during business hours to the heterosexual family life in the evenings, particularly as there was usually a "hobby" encounter" en route from work. "Sex removed the stress, and the long journey home also helped. You close the door, think about what is happening at that very moment, and sift the legal from the illegal. Everything you say has to be edited, you have to think which places to mention, which to avoid, and how to describe the day at work. Hide it deep, and put a lid on." (Ruduša 2014: 32)

The need to constantly edit what he shares makes telling the life story of a closeted gay nearly impossible - he can't present himself as a whole being because his secret would get out. He can share very limited information with both his straight and queer audiences, and he is always in danger that these audiences might mix.

\section{Memories of pleasure: short stories by Klāvs Smilgzieds}

Klāvs Smilgzieds' short stories were published in an underground gay magazine that was published in the small town of Dagda between 1994 and 2008 under various names: Zilā GAYsma (1994), GAYsma (1994-1995), Elwis (1996-2003, 2006-2008) and Jancis (2003-2005). It was a photocopied fanzine for homosexual men, made by Jancis, an enthusiast of the gay movement. It contained articles copied from official Latvian periodicals concerning gay life and celebrities, as well as personal ads and erotic photos borrowed from foreign gay magazines. Among the few original contributions were not only stories of sexual experience like the aforementioned memoirs and frequent editorials by Jancis, but also around 20 short stories by an unknown author with pen name Klāvs Smilgzieds. With the kind permission of the author and Jancis, a selection of 12 stories is 
VĒRDIN̦Š

being prepared for publication under the title Buciņš no Aunu krasta (The Buck from the Ram Coast).

Smilgzieds, now a man in his eighties, wrote these stories to support the new gay magazine and to make it more appealing to its readers (Smilgzieds 2013), so his intent was to write accessible, sexually rich gay fiction. However, these stories are not just pornographic prose - many of them don't contain any sex at all or the sex is secondary to the detailed historical background that deeply affects the relationships between gays who try to live emotionally and sexually fulfilled lives despite the challenges of the Soviet and Post-soviet environments.

The heroes of Smilgzied's fiction try to fulfil their need for man-to-man sex or to get into love relationship and maintain it, despite of the pressure of others. Being a bisexual married man himself, Smilgzieds mostly avoids depicting the inconsistencies of such a life (or, as Ruduša puts it in her interviews, "switching" from homosexual encounters to the role of family man), with the exception of one story Slappes (Thirst) where the protagonist's desired man meets him after long break and tells him about his unsuccessful marriage. Smilgzieds is not interested in female characters or in lesbian love, but focuses on male desire that is sometimes compressed in time and sometimes may last for decades. Some of these stories give the reader the impression that the author feels a light resignation while constructing his emotionally juvenile and sexually active characters. Being in his sixties and drawing on his past experience, at times the author openly reflects on his advancing years and permits himself the role of observer when orgy is taking place, as in his text Zālǐšu vakars (Grass night).

Similarity to Ruduša's interviews can be found in the geography of these stories. The action takes place mostly in the Riga city centre, providing anonymity and possibilities to meet other cruising men. Among most significant places are public toilets, and each of them has its special name in homosexual slang:

Ten years ago it would have been possible to find an understanding soul in just about any one of the public conveniences in the city centre. In the Mausoleum, the Boudoir, the Colonnade, Human Resources, the Folk Room, the Yard... If not in the first, or the second, then certainly in the third you could bet on someone already waiting. And as a last resort, there was always the Last Stop or Terminus - that is, the station. (Smilgzieds 2014b: 3)

Smilgzieds mentions also "the long circle" and "the short circle", the bars and restaurants, public baths and gay beaches, as well as leisure destinations in Russia, Petrozavodsk and Kislovodsk, as well as Palanga, a gay beach in Lithuania.

In his prose Smilgzieds also speaks of homophobic attacks that threaten homosexuals in their meeting places. In gay slang they were called 'fixers' 
('remontieri'). In his story of the same name, he organises a meeting between a gay narrator and a fixer in a park well known for being a gay cruising place (probably it was the Arkädija park in Pärdaugava). The narrator recognises the aggressiveness of the young man in front of him and starts a conversation on homosexuality and religion, analysing the fixer's homophobic passion as suppressed homosexual drive. The story ends when the narrator beats up the fixer and leaves.

Just as Smilgzieds' protagonists are of various ages, the narrative time of his stories differs. A single story can cover many years and include a lasting relationship or a chance meeting after many years where the characters lament their broken love stories or unfulfilled desires. Or a story can be about just a few hours when men meet to have quick casual sex that might turn out to be a dangerous adventure.

Stories set in nineties use the same locations and attitudes as the stories set in the Soviet era - Smilgzieds doesn't take his characters to the new gay clubs in Riga, nor does he send them to fight for the interests of LGBT community. His consciousness is clearly still dwelling in the Soviet period, when the closet was the only possibility, and is present also in his stories that are set in the nineties the switch to capitalism and the market economy leaves one of his protagonists disappointed as the free use of public toilets is over:

Now, in the wave of privatisation or the poverty and negligence of the local government, it all had been destroyed. Who's going to wait for you in a lavatory where you have to pay, where some kind of Cyclops, or more often a female gorgon, is guarding the entrance? Sometimes a gay man in Riga could feel in his heart like Adam after being banished from the gardens of Paradise. (Smilgzieds 2014b: 3)

Calling a Soviet public toilet 'Paradise' is good evidence of how homosexuals perceived their place in society. As Dan Healey has stated, public toilets in Russia were important contact venues already since the October revolution of 1917 and served this purpose until the nineties, when the first gay bars and clubs were established (Healey 2001). Still, the public toilet is the place where Smilgzieds' narrators feel most at home. This marks a difference between them and the younger generation of (post)soviet queers who, as Ruduša's interviews and other sources prove, choose different ways of contacting each other, like gay websites and clubs. 
VĒRDIN̦Š

\title{
Conclusion
}

Ruduša and Smilgzieds work in different genres and represent different perspectives. Smilgzieds is a closeted homosexual who addresses his closeted gay audience who mostly read his erotic stories in private, while Ruduša is a straight woman whose intention is to create stories to encourage public discourse. Ruduša lets her heroes tell their real life experiences, but is limited by their self-censorship and her need to present the stories to a mainstream audience. Smilgzieds, on the other hand, freely interprets his experiences, crafting his personal point of view into stories influenced by porn to make them appealing and entertaining for his closeted audience.

Still, common features in their work can be identified. Both authors draw a gay map of both Soviet and post-soviet Latvia that includes meeting places for gay people (mostly in Riga) and they both describe avenues of communication and ways of finding partners for casual sex or more lasting relationships. Both authors demonstrate the slow changes in attitude of post-soviet queers - staying in the closet still is the most popular option for contemporary gays and most consider the LGBT organizations and their fight for equality to be none of their business.

A closeted person can share only a part of his experiences without fear of public mockery and other consequences - he can show either his everyday public family man persona or tell about the secret, risky homosexual contacts with partners who know nothing of him except his need for same sex experiences. The Latvian queer narrative has yet to surface in such a way that it can influence the dominant historical narrative and add the diversity of its voices to the story.

\author{
Kārlis Vērdiñ š \\ karlis.verdins@lulfmi.lv \\ LU Literatūras, folkloras un mākslas institūts \\ Mūkusalas iela 3 \\ LV-1423, Rìga \\ LATVIJA
}

\section{Bibliography}

Akmentiņa-Smildziņa, I. 2010. Geju zēni - skaistie un pretīgie. - Kas Jauns? August 14. Garda-Rozenberga, I., ed. 2012. Dzīvesstāsts un pašapziņa: mutvārdu vēsture Latvijā. Rīga: LU FSI.

Goodwin, J. P. 1990. Gay Folklore. - W. R. Dynes, ed., Encyclopedia of Homosexuality. New York: Garland Publishing, 412-414.

Hanovs, D. 2012. Kā pētīt "nepareizas" atmiņas Latvijā? - Letonica, 2 (23), 5-24. 
Queer Male (Post)Soviet Narratives in Interviews

Healey, D. 2001. Homosexual Desire in Revolutionary Russia: The Regulation of Sexual and Gender Dissent. Chicago and London: The University of Chicago Press.

Lemke, J. 1995. Pilnīgi normāli citādi. Transl. by Pēteris Krūms. [Daugavpils]: Kukors. Lešinska, I. 1994. Homoseksuālisms mūsu vidū. - Rīgas Laiks, 11, 38-42, 68-69.

Māris 2002. Jūtu mulsums. - Elwis, September, 3 (18), 16-21, 31-37.

Mole, R. 2011. Nationality and sexuality: homophobic discourse and the 'national threat' in contemporary Latvia. - Nations and Nationalism, 17 (3), 540-560.

Ruduša, R. 2012. Pagrīdes citādība: homoseksuāḷi Padomju Latvijā. Rìga: Mansards.

Ruduša, R. 2014. Forced Underground: Homosexuals in Soviet Latvia. Riga: Mansards.

Smilgzieds, K. 2013. E-mail correspondence with the author, November, 2013.

Smilgzieds, K. 2014a. Buciņš no Aunu krasta. Manuscript.

Smilgzieds, K. 2014b. The Lad with the Foolish Smile. Transl. by Alise Avotina. Manuscript.

Thompson, P. 2000. Voice of the Past: Oral History. Third Edition. Oxford University Press.

Timofejevs-Henriksson, P. 2013. Underground Otherness: a review. - Journal of Baltic Studies, 44 (1), 111-113.

Vērdiņš, K., Ozoliṇš, J. 2013. Zilās identitātes naratīvs postpadomju Latvijā. - D. Hanovs, I. Jansone, K. Vērdiņš, eds., Dzimtes konstruēšana. Rīga: Avens un partneri, 111-128.

Waitt, G. 2005. Sexual citizenship in Latvia: geographies of the Latvian closet. - Social \& Cultural Geography, 6 (2), 161-181.

Zirnīte, M., ed. 2007. Dzīvesstāsti: vēsture, kultūra, sabiedrība. Rīga: LU FSI. 